\section{ECONOMICS}

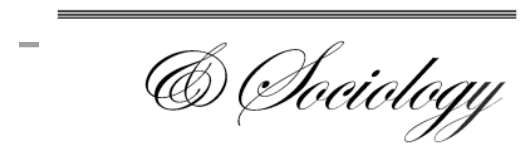

\title{
LOCAL GOVERNMENT INVOLVEMENT IN SMALL TOURISM FIRMS INVESTMENT: THE CASE OF PHU THO PROVINCE, VIETNAM
}

\author{
Ho Chi Dung, \\ Vietnam National University, \\ University of Economics and \\ Business, \\ Hanoi, Vietnam, \\ E-mail:dunghc@vnu.edu.vn
}

\author{
Pham Thi Kim Thanh, \\ National Economics University, \\ Hanoi, Vietnam, \\ E-mail: \\ thanhpham.neu@gmail.com
}

Dinh Van Oanh,
National Economics University,
Hanoi, Vietnam,
E-mail: dinhoanh.nen@gmail.com

Nguyen Hoai Long,
National Economics University,
Hanoi, Vietnam,
E-mail: longnguyenhoai@gmail.com

Received: December, 2017

1st Revision: March, 2018

Accepted: May, 2018

DOI: $10.14254 / 2071-$

789X.2018/11-2/7

JEL Classification: D02, O17, P31

\begin{abstract}
Small tourism firms in developing countries like Vietnam have proven to be a rapidly growing sector of regional tourism industries and this sector development is being promoted as a path for enhancing local economies. However, due to typical characteristics of tourism, it requires the government to play an active role in facilitating and promoting its development. The current literature is unclear regarding the relationship between small tourism firms and local government involvement. Hence, this study aims to determine the local government involvement in small firms' investment, and reports an empirical test on 209 small tourism firms in Phu Tho province, Vietnam. The results support the general hypothesis that active government involvement, both managerial and developmental, is positively related to the investment intention of small tourism firms. The research demonstrates that policy and operation implementation along with public investment in generating local tourism demand of local government have the most robust effects on these firms' investment decisions, among other factors.
\end{abstract}

Keywords: local government involvement, private investment, small firms, tourism, Vietnam.

\section{Introduction}

Social scientists have been interested in the role of government in not only political, but also social and economic life of countries for a long time. Due to the absence of a developed and innovative private sector in many developing countries, a higher level of 
intervention on the side of government is required in order to achieve material objectives (Jenkins and Henry, 1982). Explaining why governments, particularly in developing economies, take effort to boost tourism investment, it is assumed that tourism contributes significantly to their economic development (Hall \& Michael, 1991; Reid, 2003) and tourism has a higher spillover and multiplier effects in comparison to other sectors of the economy (Archer and Owen, 1971; Roe et al., 2004; Rasul and Manandhar, 2009).

Due to the highly fragmented characteristics of the tourism industry which may involve many stakeholders in the delivery of combined diverse activities and services in forming a tourism product, the government is required to play an active role in facilitating and promoting tourism development (Jenkins and Henry, 1982; Gunn, 1988; Hughes, 1994; Akama, 1997, 2002). In general, government involvement in tourism development may take different forms such as infrastructure provision, tax reduction and other concessions, or direct investment in a project, joint ventures with private enterprises (Cooper and Abubakar, 2004). It is not limited to regulatory framework like the legislative recognition of local community requirements for environmental protection and control on land use. The government roles in tourism development take place at different levels: national, regional and local governmental one (Treuren and Lane, 2003; Cooper and Abubakar, 2004).

However, there has been little attention given to investigating roles and responsibilities of local government purposefully in addressing sustainable development within tourism context (Dinica, 2009; Wray, 2009; Beaumont and Dredge, 2010; Brokaj, 2014). Therefore, our question is what is the role of local government in tourism development, particularly in attracting private investment of small firms?

Small tourism firms in developing countries including Vietnam, are proving to be a dynamically and rapidly growing in the regional tourism framework (Ateljevic and Doorne, 2003). Small firm development is being promoted as the path for enhancing local economies and offering more relevant development to marginal and/or peripheral physical, social, and cultural environments. Literature sources on tourism routinely argue that small firms depend upon institutional help when dealing with their inherent disadvantages such as managerial and operational weaknesses so that to prevent failure (Baum, 1999; Smeral, 1998; Lee-Ross, 1998; Thomas and Thomas, 1998; Ateljevic and Doorne, 2003). However, how the relationship between small tourism firms and the institutional/ public sector works is unclear.

Hence, this empirical study aims to determine how local government involvement impacts on private investment of small tourism firms in the case of Phu Tho province in Vietnam. We start with reviewing on the active involvement of local government in private investment and developing hypothesis on the relationship between managerial work as well as public investment of local government and the investment intention of small tourism firms. Next, we present the research design and the results of our survey research. Discussion on key findings and some practical implications from the research conclude our paper.

\section{Literature review}

\subsection{Active involvement of local government in private investment}

The involvement of the public sector in tourism activities, in most of the developing economies, is not only addressed in terms of long-term objectives, but also the compensation for the absence of a strong private tourism sector (Jenkins \& Henry, 1982). Therefore, in these countries, the public sector is required to contribute actively in tourism development. Active involvement is seen as deliberate action by the government, introduced to favor the tourism sector, which implies not only a recognition by government of the specific needs of the 
tourism sector, but also for its operational participation to attain stated objectives. Jenkins and Henry (1982) categorized active involvement into managerial and developmental, which intervene not only in the establishment of policies and legislative frameworks, but also in the public investment decision and management of the tourism sector.

\subsection{Managerial active involvement-tourism management}

From this aspect, local government sets tourism objectives, develops a tourism development plan, and introduces needed organizational and legislative support as well as engages officers at all level in local government system in order to attain the objectives. However, it is commonly recognized that a big gap between the planning for tourism development and its actual implementation does exist (Brokaj, 2014). Many tourism development plans fail to fulfill the objectives or even never turn into reality due to the lack of information to support planning, and the lack of effective instruments to enable implementation (Briassoulis, 2002; Michelle, 2006; Brokaj, 2014).

As in the case of Phu Tho province, the local government is questioning the effectiveness and efficiency of their tourism development plan and their operational programs in attracting the private investment to stimulate the tourism industry of the province. They have developed an overall plan for tourism development in both long term and short term. They have established a policy framework supporting the tourism sector. Local officials announced their commitment to the development of tourism sector in our interviews . Therefore, digging into the reason why this gap between ideas and practice exists would bring this problem into light and suggest some proper solutions for it.

This study aims to determine the effects of active involvement of local government in private investment of small tourism firms through testing how local planning initiative, policy framework, policy and operation program implementation, and local government officials involvement affect investment intention of small tourism firms within the province. Better understanding of these relationships is expected to be good measures for local government in tourism management. We accordingly hypothesize:

H1: Tourism planning initiative of local government is positively related to the investment intention of small tourism firms.

$\mathrm{H} 2$ : Local government's policy framework supporting tourism sector is positively related to the investment intention of small tourism firms.

H3: The implementation of policy and operation programs of local government is positively related to the investment intention of small tourism firms.

$\mathrm{H} 4$ : The extent to which local government officials devote to local tourism development is positively related to the investment intention of small tourism firms.

\subsection{Developmental active involvement - public investment in tourism}

Developmental involvement is seen when the government or its agencies undertake an operational role in the tourist sector (Jenkins and Henry, 1982). In most of developing transitional economies, it requires the involvement of public sector or public investment in tourism activities is required not only to achieve long-term objectives, but also to make up for the lack of robust tourism-experienced private sector. Aschauer (1989b) brought the subject of the effects of public investment on private output to the limelight and ever since has generated great interest in the literature. It was quickly recognized that public investment affects private output directly as well as on private input, particularly private investment (Pereira, 2001). 


\subsubsection{Relationship between public investment and private investment}

From reviewing the available theoretical and empirical literature, the effects of public investment on private investment have proven inverse evidence (Nawaz and Hassan, 2016). A number of studies argued that public investment facilitates and stimulates private investment in different way such as by providing infrastructural support, or types of immediate public goods, etc. (Kenneth and Kurz, 1970; Blejer and Khan, 1984; Barro, 1990; Costa et al., 1987; Deno, 1988; Argimon et al., 1997; Hassan et al., 2011; Nazmi and Ramirez, 1997; Zugasti et al., 2001; Ghani and Din, 2006; Nawaz and Hassan, 2016).

On the contrary, a number of other research works, Phetsavong and Ichihashi (2012), for instance, supported the view of the crowding out effect of public investment on private investment. The crowding out effect is argued to become visible if the public sector invests in the cost of increased interest rates and taxes, or if the public sector competes with the private sector directly with additional investment spending. In addition, if public sector utilizes both financial and physical resources, which would alternatively be used by the private sector, it can crowd out private investments as well (Aschauer, 1989; Blejer \& Khan, 1984, Nawaz and Hassan, 2016). In some studies, public investments completely crowd out private investment (Keran, 1969, 1970; Nawaz and Hassan, 2016), while there are evidences of partial crowding out in other studies (Abrams and Schitz, 1978; Arestis and Karakitsos, 1982; Cebula et al., 1981; Lombra and Torto, 1974; Zahn, 1978; Nawaz and Hassan, 2016). Bennett (1983) argues that government spending on roads, public housing and airports can either stimulate or retard, or even have no effect on private investment spending (Nawaz and Hassan, 2016).

In the context of developing countries, public investment is seen as a significant, but it either affects negatively or crowds out private investment in Asean countries (Bende-Nabende and Slater, 2003; Nawaz and Hassan, 2016). Likewise, studies using data panel of developing countries confirmed public investment's role as stimuli for private investment (for example, Blejer and Khan, 1984; Greene and Villanueva, 1991; Odedokun, 1997; Ahmed and Miller, 2000; Ghura and Goodwin, 2000; Erden and Holcombe, 2005). However, these studies contended that public investment in infrastructure development positively affects private investment, but non-infrastructure public investment affects private investment negatively.

Therefore, this issue is far from being unanimous or conclusive. It means that it is not clear whether there exists a crowding-out or crowding-in effect of public investment on private investment or not.

In tourism, particularly, it is argued that the high risk of investment in tourism enhances public and private sector collaboration in order to ensure the security of private investors (Petrescu, 2011). The public sector helps to create favorable socio-economic and political environment, as well as establishes and provides transport infrastructure, communication network, promotion of arts and craft, and development of museums and heritage preservation, etc. for the private investment to attain a sustainable development in the tourism industry (Akama, 2002). For developing countries like Kenya, the role of government is assumed to be vital in the tourism development as the country's tourism ministry initiates and promotes both FDI and local investment in the tourism sector. However, empirical research on how the public investment influences the private investment in tourism is still sparse.

In this study, we aim to investigate the effects of government's developmental active involvement in private investment by testing how public investment in tourism affects the investment intention of small tourism firms. Public investment in tourism would directly influence private input (Akama, 2002) like investment in infrastructure, in preservation and development of heritage, in supporting tourism community like households, traditional 
villages, and so on. We consider other public investments engaged in generating demands for local tourism, for example, public investment in promoting local tourism products, building tourism brand image for the province, etc (Nawaz and Hassan, 2016). These investments are assumed to indirectly affect private input through reducing the expenditure for promotion for instance, and positively affect private output. Therefore, we hypothesize:

H5: Local government's public investment that directly influences private input is positively related to the investment intention of small tourism firms.

H6: Local government's public investment in generating demands for local tourism is positively related to the investment intention of small tourism firms.

\section{Methodological approach}

\subsection{Research site}

Phu Tho is a province in the Northern midland mountainous region, the gateway to the Northwest of Hanoi capital, the transshipment points between the East and North West, one of the localities with great tourism potential and many advantages to develop tourism. Situated in the interchange area between the Northeast, the Red River Delta and the Northwest rocky area, the geographic location as the central West-North-East sub-region, which offers the advantage of a regional tourist development link. The natural conditions of Phu Tho, especially the diverse midland terrain, have made Phu Tho a relatively rich and attractive natural tourist resource to develop different types of tourism such as sightseeing, recreation, medical treatment, sports and ecotourism, etc.

Phu Tho has a bright long history, which has cultivated a valuable cultural heritage. It highlights the historical relics of the Hung Temple, which is recognized as a national-level special historical and cultural monument associated with Hung King's death anniversary festival. Every year it attracts a large number of Vietnamese tourists from all over the country. Among those special cultural features is Xoan singing, which is recognized by UNESCO as a World Cultural Heritage.

However, beside the achievements in the past years, Phu Tho tourism has experienced many shortcomings, difficulties and obstacles. There has not been any breakthrough to confirm the real economic spearhead; the results do not reflect the potential and advantages of the province. For these reasons, the problem posed to Phu Tho authorities is how to encourage small firms in tourism sector to increase investment.

\subsection{Research design}

The desk research method is used to gather the information on:

- Current literature on local government involvement and private investment in tourism.

- The activities to attract investment and tourism development of Phu Tho province authorities.

This stage helped us identify the research framework and select the model for studying the influence of local government involvement on investment intentions in tourism of small firms, including six factors: planning initiative, policy framework, policy and operation implementation, local officers, public investment in private input and public investmet in generating local tourism demands. The qualitative interview guidelines were designed accordingly.

Focus group interview method is used in stage 2 of quanlitative research with the sample of 4 groups of tourism firm leaders. The content of the group discussion focused on 
policy issues and policy implementation; local officers managing the operations of enterprises of the tourism industry; public investment, and the influences of these factors on the investment intention of these enterprises. Based on the research results, we developed a list of six factors influencing the investment intention in tourism of small firms in Phu Tho. The questionnaire for the preliminary quantitative research was developed accordingly.

We conducted preliminary quantitative research with 30 leaders of tourism firms in Phu Tho to evaluate the questionnaire and the items in order to standardize questionnaires for official investigation. The collected data were processed using SPSS software version 22. At this stage, we assessed the reliability of the factors in the model (through the Cronbach Alpha test) and shortened the investigating factors through factor analysis to refine the research model against the original theoretical model. Cronbach alpha coefficient and the item-total correlation are used to evaluate the suitability of each observation variable with the factors. Accordingly, the observed variables with Cronbach Alpha $<0.7$ and Item-total correlation $<0.3$ will be excluded from the model (Nunnally and Burnstein, 1994). Observation factors with factor loading less than 0.4 in EFA will continue to be eliminated (Gerbing and Anderson, 1988) and test the total covariance deviation asked which is greater than $50 \%$. The results of the data analysis eliminated 04 observation variables. The final derived items in six factors includes: six items for factor Tourism planning initiative; five items for factor Policy framework supporting tourism sector, five items for factor The implementation of policy and operation programs, five items for factor Local government officer, three items for factor Public investment that directly influences private input and four items for factor Public investment in generating demands. Base on that, the official questionnaire for data collecting were completed.

In official quantitative research, the data collection was conducted using intervieweradministered survey in December 2017. The interviewees were firms and business households registered to serve tourists at Phu Tho Department of Culture, Sports and Tourism in the field of travel business. A stratified sampling technique was used to generate a sample based on types of business. The specific survey structure is as follows.

Table 1. Interview sample structure based on types of business

\begin{tabular}{lcccc}
\hline Business types & $\begin{array}{c}\text { Number } \\
\text { of enterprises/ } \\
\text { business } \\
\text { households }\end{array}$ & $\begin{array}{c}\text { Number } \\
\text { of people } \\
\text { expected } \\
\text { to interview }\end{array}$ & $\begin{array}{c}\text { Number of } \\
\text { valid votes }\end{array}$ & $\begin{array}{c}\text { Interviewee } \\
\text { structure }\end{array}$ \\
\hline Specialized in travel business & 16 & 8 & 8 & $3.80 \%$ \\
\hline Specialized in hotels & 88 & 44 & 42 & $20.10 \%$ \\
\hline Specialized in restaurant & 153 & 76 & 74 & $35.40 \%$ \\
\hline Dedicated services in the destination & 132 & 66 & 65 & $31.10 \%$ \\
\hline $\begin{array}{l}\text { Specialized in tourist transportation } \\
\text { services }\end{array}$ & 17 & 8 & 8 & $3.80 \%$ \\
\hline Trading a wide range of travel services & 25 & 12 & 12 & $5.70 \%$ \\
\hline Total & 431 & 214 & 209 & $100 \%$ \\
\hline
\end{tabular}

Source: Survey data of research team, 2017.

Data processing: Factor analysis method (EFA) and the regression analysis method were used to analyze the data with SPSS software.

Finally, we conducted in-depth interviews with 06 tourism firm leaders to discuss issues related to the quantitative research results to gain insights into the small firms' 
investment intention and explanation of the research findings. We also looked for suggestion of proper solutions to leverage the local goverment involvement in investment intention of small firms in tourism industry.

\section{Conducting research and Results}

\subsection{Investors' assessment of the involvement of Phu Tho authorities}

The study uses the Likert scale from 1 to 5 . The average score of $1-1.8$ is equivalent to very poor; the range of $1.8-2.6$ is equivalent to poor level; the range of $2.6-3.4$ is equivalent to average; the range of $3.4-4.2$ is equivalent to good and the range of $4.2-5$ is very good. The assessment results show that the items describing the involvement of Phu Tho authorities that impacts on the investment intention of small firms in the province are in two ranges - average and good. The group of elements which are evaluated at good level are presented in Table 2 below.

Table 2. Elements evaluated at good level

\begin{tabular}{|c|c|c|}
\hline Factor & Item & Mean \\
\hline $\begin{array}{l}\text { Tourism planning } \\
\text { initiative }\end{array}$ & $\begin{array}{l}\text { The suitability between the provincial tourism development } \\
\text { strategy with the national tourism development strategy }\end{array}$ & 3.49 \\
\hline \multirow{5}{*}{$\begin{array}{l}\text { Policy framework } \\
\text { supporting tourism } \\
\text { sector }\end{array}$} & $\begin{array}{l}\text { The consistency between tourism development policies and the } \\
\text { provincial strategies }\end{array}$ & 3.48 \\
\hline & $\begin{array}{l}\text { The policy to encourage and support tourism firms to operate in } \\
\text { the province }\end{array}$ & 3.56 \\
\hline & The policy to manage tourism business activities & 3.56 \\
\hline & $\begin{array}{l}\text { The policy to attract and develop human resources in tourism of } \\
\text { the province }\end{array}$ & 3.64 \\
\hline & The policy to preserve and develop the provincial tourism products & 3.81 \\
\hline $\begin{array}{l}\text { The implementation } \\
\text { of policy and } \\
\text { operation programs }\end{array}$ & $\begin{array}{l}\text { The activities of state management agencies in propagating } \\
\text { strategies and policies for Phu Tho tourism development }\end{array}$ & 3.50 \\
\hline \multirow{2}{*}{$\begin{array}{l}\text { Local government } \\
\text { officer }\end{array}$} & $\begin{array}{l}\text { The awareness of civil servants about the policies to encourage } \\
\text { the provincial tourism development }\end{array}$ & 3.47 \\
\hline & Effort of civil servants to develop tourism in the province & 3.60 \\
\hline \multirow{3}{*}{$\begin{array}{l}\text { Public investment } \\
\text { that directly } \\
\text { influences private } \\
\text { input }\end{array}$} & $\begin{array}{l}\text { Investment of the province to ensure the tourism landscape and } \\
\text { environment }\end{array}$ & 3.65 \\
\hline & Investment of the province for the tourism business community & 3.72 \\
\hline & $\begin{array}{l}\text { Provincial investment in tourism preservation and resource } \\
\text { development }\end{array}$ & 3.63 \\
\hline \multirow{3}{*}{$\begin{array}{l}\text { Public investment in } \\
\text { generating demands }\end{array}$} & Provincial investment to develop entertainment areas & 3.67 \\
\hline & Provincial investment in promoting tourism products & 3.52 \\
\hline & Provincial investment in tourism branding development & 3.49 \\
\hline
\end{tabular}

Source: Survey data processing results of research team, 2017.

Thus, each factor of the "Tourism planning initiative" and the factor "The implementation of policy and operation programs" has only one item that are rated as good by 
investors, namely "The suitability of the provincial tourism development strategy with the national tourism development" and the "Operation of state management agencies in the propaganda of Phu Tho tourism development strategies and policies". All the items of the factor "Policy framework supporting tourism sector" and the factor "Public investment in generating demands"; $3 / 4$ items of the factor " Public investment that directly influences private input" are evaluated as good by the investors. This shows that investors have recognized the effort of $\mathrm{Phu}$ Tho province state management agencies in implementing tourism development policies in provincial marketing activities in increasing tourists' demand to Phu Tho province. Investors also note the provincial marketing activities to promote private investment in the tourism sector. However, the mean value of the items are all below 3.7 indicating that Phu Tho province still needs to make further efforts to enhance their active involvement in attracting investment of tourism firms.

Table 3. Elements evaluated at average level

\begin{tabular}{|c|c|c|}
\hline Factor & Items & Mean \\
\hline \multirow{5}{*}{$\begin{array}{l}\text { Tourism planning } \\
\text { initiative }\end{array}$} & $\begin{array}{l}\text { The suitability of the provincial tourism development strategy } \\
\text { with Phu Tho resources and tourism resources }\end{array}$ & 3.21 \\
\hline & $\begin{array}{l}\text { The suitability of the tourism development strategy of the } \\
\text { province with the needs of visitors }\end{array}$ & 3.36 \\
\hline & $\begin{array}{l}\text { The support of the public in the province for Phu Tho tourism } \\
\text { development strategy }\end{array}$ & 3.32 \\
\hline & $\begin{array}{l}\text { The support of state management agencies in the province for } \\
\text { Phu Tho tourism development strategy }\end{array}$ & 3.21 \\
\hline & $\begin{array}{l}\text { The support of investors to the tourism development strategy in } \\
\text { the province }\end{array}$ & 3.30 \\
\hline \multirow{4}{*}{$\begin{array}{l}\text { The implementation } \\
\text { of policy and } \\
\text { operation programs }\end{array}$} & $\begin{array}{l}\text { The compliance of state management agencies for the tourism } \\
\text { development policy in the province }\end{array}$ & 3.15 \\
\hline & $\begin{array}{l}\text { The flexibility of the state management agencies in the } \\
\text { implementation of Phu Tho tourism development policy }\end{array}$ & 3.10 \\
\hline & $\begin{array}{l}\text { The development of the provincial action plan to implement the } \\
\text { tourism development policies }\end{array}$ & 3.23 \\
\hline & $\begin{array}{l}\text { The suitability of the tourism development action plan with the } \\
\text { context of the province }\end{array}$ & 3.36 \\
\hline \multirow{3}{*}{$\begin{array}{l}\text { Local government } \\
\text { officer }\end{array}$} & Professional capacity of civil servant in the province & 3.34 \\
\hline & $\begin{array}{l}\text { The trust of civil servants in the provincial tourism development } \\
\text { encouraging policies }\end{array}$ & 3.25 \\
\hline & $\begin{array}{l}\text { The compliance of the provincial tourism development } \\
\text { encourages policies of civil servants }\end{array}$ & 3.27 \\
\hline $\begin{array}{l}\text { Public investment } \\
\text { that directly } \\
\text { influences private } \\
\text { input }\end{array}$ & Provincial investment in infrastructure development. & 3.28 \\
\hline
\end{tabular}

Source: Survey data processing results of research team, 2017.

Most of the items belong to the factors "Tourism planning initiative", "The implementation of policy and operation programs" and "Local government officer" are only rated 
by investors as average. This shows that Phu Tho needs to concentrate more efforts to build trust and support for the province's tourism development strategy, incentive programs for tourism development and capacity building as well as the awareness and discipline of civil servants.

Except for the item "Provincial investment in infrastructure development", all the items related to investment are well appreciated. This indicates that Phu Tho province has been well implementing its investment activities for tourism development.

\subsection{EFA analysis results}

Results from EFA analysis exhibit that from 29 observed variables, 6 factors can be derived based on the Eigenvalues $>1$. These six factors explain $68.99 \%$ of the variance of the data. Thus, it is possible to use these 6 factors to carry out the next steps of the study.

Using the rotated component matrix reveals the 6 factors that comprise the specific items as follows. Factor 1 (named Planning Initiative) consists of 6 items from PI1=>PI6. Factor 2 (named Policy Framework) includes 5 items PF1=>PF5. Factor 3 (named Policy and Operation Implementation) includes 5 items from POI1=>POI5. Factor 4 (named Local Officer) consists of 6 items LO1=>LO6. Factor 5 (named Public Investment on Private Input) contains 3 items PPI1=>PPI3. The remaining factor (factor 6) is named Local Tourism Demand (including 4 items LTD1=>LTD4). Since the items are related to the corresponding factors (coefficient $>0.5$ ), they are all retained.

Table 4. Rotated Component Matrix ${ }^{\mathrm{a}}$

\begin{tabular}{|c|c|c|c|c|c|c|}
\hline \multirow{2}{*}{ Description } & \multicolumn{6}{|c|}{ Component } \\
\hline & 1 & 2 & 3 & 4 & 5 & 6 \\
\hline $\begin{array}{l}\text { LO1 The professional capacity of civil servants } \\
\text { in the province. }\end{array}$ & & & & .525 & & \\
\hline $\begin{array}{l}\text { LO2 Awareness of civil servants on tourism } \\
\text { development policy in the province. }\end{array}$ & & & & .764 & & \\
\hline $\begin{array}{l}\text { LO3 The trust of civil servants in the tourism } \\
\text { development policy in the province. }\end{array}$ & & & & .573 & & \\
\hline $\begin{array}{l}\text { LO4 The compliance with the provincial } \\
\text { tourism development policy of civil servants. }\end{array}$ & & & & .695 & & \\
\hline $\begin{array}{l}\text { LO5 The efforts of civil servants to develop } \\
\text { tourism in the province. }\end{array}$ & & & & .772 & & \\
\hline $\begin{array}{l}\text { PI1 The suitability of the provincial tourism } \\
\text { development strategy with the national tourism } \\
\text { development strategy. }\end{array}$ & .749 & & & & & \\
\hline $\begin{array}{l}\text { PI2 The suitability of the provincial tourism } \\
\text { development strategy with Phu Tho resources } \\
\text { and tourism resources. }\end{array}$ & .850 & & & & & \\
\hline $\begin{array}{l}\text { PI3 The suitability of the provincial tourism } \\
\text { development strategies with the tourists' } \\
\text { demands. }\end{array}$ & .830 & & & & & \\
\hline $\begin{array}{l}\text { PI4 Public support in the province for Phu Tho } \\
\text { tourism development strategy. }\end{array}$ & .804 & & & & & \\
\hline $\begin{array}{l}\text { PI5 The support of the provincial state } \\
\text { management agencies towards Phu Tho } \\
\text { tourism development strategy. }\end{array}$ & .823 & & & & & \\
\hline $\begin{array}{l}\text { PI6 The support of investors to the provincial } \\
\text { tourism development strategy. }\end{array}$ & .742 & & & & & \\
\hline
\end{tabular}


POI1 Activities of state management agencies in propagating Phu Tho tourism development .619 policies and strategies.

POI2 The compliance of state management policies with the provincial tourism

development policies.

POI3 The flexibility of state management agencies in implementing Phu Tho tourism development policies.

POI4 The development of the province's action plan to implement tourism development policies.

POI5 The relevance between the tourism development action plan to the provincial context.

PF1 The consistency between the provincial tourism development policies and strategies.

PF2 The policy to encourage and support tourism enterprises to operate in the province.

PF3 The policy on managing the tourism business policy.

PF4 The policy to attract and develop human resources for tourism of the province.

PF5 The policy on preservation and development of the provincial tourism

products.

PPI1 The provincial investment to develop recreational areas.

PPI2 The provincial investment in promoting tourism products.

PPI3 The provincial investment in tourism brand development.

LTD1 The provincial investment in infrastructure development. .503

LTD2 The provincial investment to ensure the landscape and tourism development. .866

LTD3 The provincial investment in the tourism business community.

LTD4 The provincial investment in the conservation and development of tourism .832 resources.

Source: Survey data processing results of research team, 2017.

\subsection{Results of regression analysis}

The results of the regression model (with independent variables being F1 - F6 factors and the dependent variable being investment intention item - Table 5) show that the value of the adjusted coefficient $R^{2}$ is 0.468 . Although this value is less than 0.5 but according to Hair et al. (1980), for socio-economic studies this value is acceptable. In other words, the intention to invest in business expansion of enterprises is also influenced by factors outside of this research. In addition, the dependent variable "investment intention" is explained quite well by 
6 independent variables in model. The Durbin-Watson coefficient $=1.199$ indicates that the model does not violate the multiple regression method and allow us to accept the hypothesis of no top-level correlation in the model. Thus, the multiple regression models satisfy the conditions for assessment and validation for the derivation of the research results.

Table 5. Results of the multiple linear regression analysis

\begin{tabular}{lccccc}
\hline Model & R & R Square & Adjusted R Square & Se & Durbin-Watson \\
\hline 1 & $.695^{\mathrm{a}}$ & .483 & .468 & .601 & 1.199 \\
\hline
\end{tabular}

Table 6. ANOVA ${ }^{\mathrm{a}}$

\begin{tabular}{llccccc}
\hline & Model & Sum of Squares & df & Mean Square & F & Sig. \\
\hline 1 & Regression & 68.186 & 6 & 11.364 & 31.442 & $.000^{\mathrm{b}}$ \\
\cline { 2 - 7 } & Residual & 73.010 & 202 & .361 & & \\
\cline { 2 - 7 } & Total & 141.196 & 208 & & & \\
\hline
\end{tabular}

Source: Survey data processing results of research team, 2017.

Table 6 divulges value $\mathrm{F}=31.442$; value $\operatorname{sig}=0.000$ means that this relationship ensures a level of allowed confidence of 5\%. The F1-F6 factors explain $46.8 \%$ of the variance of the intended investment variable.

Table 7. Coefficients ${ }^{\mathrm{a}}$

\begin{tabular}{|c|c|c|c|c|c|c|c|}
\hline \multirow{2}{*}{ Model } & \multicolumn{2}{|c|}{$\begin{array}{c}\text { Unstandardized } \\
\text { Coefficients }\end{array}$} & \multirow{2}{*}{$\begin{array}{c}\begin{array}{c}\text { Standardized } \\
\text { Coefficients }\end{array} \\
\text { Beta } \\
\end{array}$} & \multirow[t]{2}{*}{$\mathrm{t}$} & \multirow{2}{*}{ Sig. } & \multicolumn{2}{|c|}{$\begin{array}{l}\text { Collinearity } \\
\text { Statistics }\end{array}$} \\
\hline & $\mathrm{B}$ & Std. Error & & & & Tolerance & VIF \\
\hline (Constant) & 3.344 & .042 & & 80.424 & .000 & & \\
\hline Planning initiative & .118 & .042 & .143 & 2.819 & .006 & 1.000 & 1.000 \\
\hline Policy framework & .113 & .042 & .137 & 2.703 & .010 & 1.000 & 1.000 \\
\hline $\begin{array}{l}\text { Policy \& operation } \\
\text { implementation }\end{array}$ & .439 & .042 & .533 & 10.530 & .000 & 1.000 & 1.000 \\
\hline Local officers & .144 & .042 & .175 & 3.453 & .000 & 1.000 & 1.000 \\
\hline $\begin{array}{l}\text { Public investment on } \\
\text { private input }\end{array}$ & .127 & .042 & .155 & 3.056 & .004 & 1.000 & 1.000 \\
\hline Local tourism demand & .268 & .042 & .325 & 6.423 & .000 & 1.000 & 1.000 \\
\hline
\end{tabular}

Source: Survey data processing results of research team, 2017.

The variable multipliers (VIF) of independent variables in the model are < 2 (Table 7), which demonstrates the multi-linearity of the independent variables is not remarkable and the variables in the model are acceptable.

The regression analysis results affirm that the independent variables affect the firm's "investment intention". The relationship between the dependent variable "investment intention" and 6 independent variables is demonstrated in the following equation:

$$
\mathrm{Y}=3.344+0.118 \mathrm{X} 1+0.113 \mathrm{X} 2+0.439 \mathrm{X} 3+0.144 \mathrm{X} 4+0.127 \mathrm{X} 5+0.268 \mathrm{X} 6
$$

It is shown that planning initiative (X1), policy framework (X2), policy and operation implementation (X3), local officers (X4), public investment directly relating to private input 
(X5), public investment in local tourism demand generation (X6) all are positively related to private investment intention.

The objective of this study was to determine the relationship between the investment intention of the tourism firms and the elements of the local tourism planning initiative; local policy framework in tourism; policy and operation program implementation; local officials involvement; public investment relates to private investment intention. The results of factor analysis and regression presented that all the five hypotheses were accepted.

The research results show the two factor groups that most strongly influence the investment expansion intention are (1) policy and operation implementation and (2) public investment in local tourism demand generation. These findings suggest that in order to encourage small businesses to expand their investment in tourism, local authorities should focus on improving the quality and effectiveness of implementing tourism development policies as well as making business owners aware of the government's efforts.

\subsubsection{Other results}

Quantitative research results indicate that there are six factors influencing the intention to expand business investment of small-scale tourism firms. However, within the scope of this paper, the research team only focuses on explaining the influential causes of the two factors "policy and operation implementation và "public investment in local tourism demand generation". These are the two most important factors influencing the investment intention of the enterprise: (1) In Vietnam in general and in Phu Tho in particular, there is a lag between the policy issuance and implementation. This lag is quite long in some cases. In some other cases, the implementation of the policy has been unsuccessful. Small firms, therefore, will feel more secured when the authorities actually take action which shows results. In addition, the strong influence of public investment in local tourism demand generation shows the limited capacity of business leaders and the relatively high passivity of small firms in investment to seize business opportunities. They look forward to the pioneering role of local authorities in exploring the market. This again confirms the key role of the authorities in implementing tourism development policies.

Under the conditions of Phu Tho province, where most of tourism firms are small ones, management level and business autonomy are limited, the pioneer of the government in tourism developmental investment will motivate these firms to invest more. This finding contributes to the situation that, despite the fact that both the provincial government and firms have potential for development, Phu Tho tourism is still in the early stages of the development cycle of this industry.

\section{Conclusion}

This study confirms the positive relationship between the active government involvement and the private investment intention. It has added to the sparse literature on the impact of the local government on the private investment of small tourism firms. The study finds that the local investment in attracting tourists to the province, which does not directly impact the input of the firms though, has a great impact on their investment intentions.

Policy implication: The research points out two factors of local government involvement that have the most robust impact on tourism firms' investment intention, namely policy and operation implementation, and investment in local tourism demand generation to Phu Tho. Therefore, Phu Tho province authorities should focus on monitoring policies and developing specific mechanisms to encourage the government agencies at all levels from the 
province to county and commune, as well as professional agencies involved in the tourism industry to implement incentive policies in tourism. Phu Tho government should also allocate more investment in generating demands for local tourism, and improve the efficiency of the public investment. To do this, Phu Tho may focus on two directions: (1) develop incentives to attract tourists to local spiritual destinations on off-festival seasons; (2) invest in enhancing the link and network of destinations, developing and promoting local specialties and services for tourists to keep the tourists stay longer, hence increase their expenditure in Phu Tho.

\section{Acknowledgement}

The authors are thankful to the Vietnam National University, Hanoi (VNU), under project number QG.15.39, for financial support to carry out this research.

\section{References}

Abrams, B. A., \& Schitz, M. D. (1978). The 'crowding-out'effect of governmental transfers on private charitable contributions. Public Choice, 33(1), 29-39. Retrieved October 3, 2017, from https://doi.org/10.1007/BF00123940.

Ahmed, H., \& Miller, S. M. (2000). Crowding-out and crowding-in effects of the components of government expenditure. Contemporary Economic Policy, 18(1), 124-133. doi:10.1111/j.1465-7287.2000.tb00011.x.

Akama, J. S. (1997). Tourism development in Kenya: Problems and policy alternatives. Progress in Tourism and Hospitality Research, 3(2), 95-105. doi:10.1002/(SICI)10991603(199706)3:2<95::AID-PTH58>3.0.CO;2-P.

Akama, J. S. (2002). The role of government in the development of tourism in Kenya. International Journal of Tourism Research, 4(1), 1-14. doi:10.1002/jtr.318.

Archer, B. H., \& Owen, C. B. (1971). Towards a tourist regional multiplier. Regional studies, 5(4), 289-294. Retrieved October 3, 2017, from https://doi.org/10.1080/09595237100185331.

Arestis, P., \& Karakitsos, E (1982). Crowding out in the UK within an Optimal Control Framework. Journal of Public Policy, 2(1), 31-51. Retrieved October 5, 2017, from https://doi.org/10.1017/S0143814X00001781.

Argimon, I., Gonzalez-Paramo, J. M., \& Roldan, J. M. (1997). Evidence of public spending crowding-out from a panel of OECD countries. Applied Economics, 29(8), 1001-1010. Retrieved October 5, 2017, from https://doi.org/10.1080/000368497326390.

Aschauer, D. A. (1989). Does public capital crowd out private capital? Journal of Monetary Economics, 24(2), 171-188. doi: 0.1016/0304-3932(89)90002-0.

Ateljevic, J., \& Doorne, S.(2004). Diseconomies of scale: A study of development constraints in small tourism firms in central New Zealand. Tourism and Hospitality Research, 5(1), 5-24. doi:10.1057/palgrave.thr.6040002.

Barro, R. J. (1990). Economic growth and convergence across the United States (No. w3419). National Bureau of Economic Research.

Baum, T. (1999). Human resource management in tourism's small business sector: Policy dimensions. In: HRM in Tourism and Hospitality: Inter-national Perspectives on Small to Medium-sized Enterprises, 3-16.

Blejer, M. I., \& Khan, M. S. (1984). Government Policy and Private Investment in Developing Countries (Politique des pouvoirs publics et investissement privé dans les pays en développement) (Política estatal e inversión privada en los países en desarrollo). Staff Papers-International Monetary Fund, 31(2), 379-403. doi: 10.2307/3866797. 
Briassoulis, H. (2002). Sustainable Tourism and the Question of the Commons. Annals of Tourism Research, 29(4), 1065-1085.doi:10.1016/S0160-7383(02)00021-X.

Brokaj, R. (2014). Local Governments role in the sustainable tourism development of a destination. European Scientific Journal, ESJ, 10(31).

Cebula, R. J., Carlos, C., \& Koch, J. V. (1981). The 'crowding out' effect of federal government outlay decisions: An empirical note. Public Choice, 36(2), 329-336. Retrieved October 5, 2017, from https://doi.org/10.1007/BF00123789.

Cooper, M. \& Flehr, M. (2006). Government Intervention in Tourism Development: Case Studies from Japan and South Australia. Current Issues in Tourism, 9(1), 69-85. doi:10.1080/13683500608668239.

Costa, J. d. S., Ellson, R. W., \& Martin, R. C. (1987). Public capital, regional output, and development: Some empirical evidence. Journal of Regional Science, 27(3), 419-437. doi: 10.1111/j.1467-9787.1987.tb01171.x.

Deno, K. T. (1988). The effect of public capital on US manufacturing activity: 1970 to 1978. Southern Economic Journal, 55(2), 400-411. doi: 10.2307/1059112.

Erden, L., \& Holcombe, R. G. (2005). The effects of public investment on private investment in developing economies. Public Finance Review, 33(5), 575-602. doi: $10.1177 / 1091142105277627$.

Ghani, E., \& Din, M.-u. (2006). The impact of public investment on economic growth in Pakistan. The Pakistan Development Review, 87-98.

Ghura, D., \& Goodwin, B. (2000). Determinants of private investment: A cross-regional empirical investigation. Applied Economics, 32(14), 18191829. doi:10.1080/000368400425044.

Greene, J., \& Villanueva, D. (1991). Private investment in developing countries: An empirical analysis. Staff Papers-International Monetary Fund, 38(1), 33-58. https://doi.org/10.2307/3867034.

Gunn, C. (1988). Tourism Planning: Basic Concepts Cases. Taylor \& Francis: Washington, DC.

Hair, J. F., Black, W. C., Babin, B. J., Anderson, R. E., \& Tatham, R. L. (1998). Multivariate data analysis. Upper Saddle River, NJ: Prentice hall, 5(3), 207-219.

Hall, \& Michael, C. (1991). Introduction to Tourism in Australia: Impacts. Planning and Development: Longman Cheshire.

Hassan, S., Othman, Z., \& Karim, M. Z. A. (2011). Private and public investment in Malaysia: A panel time-series analysis. International Journal of Economics and Financial Issues, 1(4), 199. Retrieved October 6, 2017, from https://search.proquest.com/openview/954a301d89c15a209ca10300ad30f9cb/1?pqorigsite $=$ gscholar $\& \mathrm{cbl}=816338$.

Hughes, H. (1994). Tourism and government: a subset of leisure policy? In Tourism: The State of the Art, Seaton A (ed.), 472-480.

Jenkins, C. L., \& Henry, B. M. (1982). Government involvement in tourism in developing countries. Annals of Tourism Research, 9(4), 499-521. doi:10.1016/01607383(82)90070-6.

Kenneth, J. A., \& Kurz, M. (1970). Public Investment, the Rate of Return, and Optimal Fiscal Policy: Baltimore. $M D$.

Lee-Ross, D. (1998). Comment: Australia and the small to medium-sized hotel sector. International Journal of Contemporary Hospitality Managemen, 10(5), 177-179. doi: 10.1108/09596119810227703. 
Lombra, R. E., \& Torto, R. G. (1974). Measuring the impact of monetary and fiscal actions: A new look at the specification problem. The Review of Economics and Statistics, 56(1), 104-107. doi: 10.2307/1927533.

Nawaz, M. A., \& Hassan, S. (2016). Investment and Tourism: Insights from the Literature. International Journal of Economic Perspectives, 10(4), 581-590.

Nazmi, N., \& Ramirez, M. D. (1997). Public and private investment and economic growth in Mexico. Contemporary Economic Policy, 15(1), 65-75. doi: 10.1111/j.14657287.1997.tb00455.x.

Odedokun, M. O. (1997). Relative effects of public versus private investment spending on economic efficiency and growth in developing countries. Applied Economics, 29(10), 1325-1336. doi:10.1080/00036849700000023.

Pereira, A. M. (2001). On the effects of public investment on private investment: what crowds in what? Public Finance Review, 29(1), 3-25. doi:10.1177/109114210102900101.

Petrescu, R. M. (2011). The involvement of the public and private sector - Elements with influence on travel \& tourism demand during the crisis period. Tourism and Hospitality Management, 17(2), 217-230.

Ramirez, M. D. (2000). The impact of public investment on private investment spending in Latin America: 1980-95. Atlantic Economic Journal, 28(2), 210-225. Retrieved October 6, 2017, from https://doi.org/10.1007/BF02298362.

Rasul, G., \& Manandhar, P. (2009). Prospects and Problems in Promoting Tourism in South Asia: A Regional Perspective. South Asia Economic Journal, 10(1), 187-207. Retrieved October 6, 2017, from https://doi.org/10.1177/139156140901000108.

Reid, D. G. (2003). Tourism, Globalization and Development: Responsible Tourism Planning. Pluto Press London.

Ribariæ, H., \& Ribariæ, I. (2013). Government intervention in driving the development of sustainable tourism. Paper presented at the 2nd International Scientific Conference Tourism in South East Europe 2013.

Roe, D., Ashley, C., Page, S., \& Meyer, D. (2004). Tourism and the poor analyzing and interpreting tourism statistics from a poverty perspective.

Smeral, E. (1998). The impact of globalisation on small and medium enterprises: New challenges for tourism polices in European countries. Tourism Management, 19(4), 371380. https://doi.org/10.1016/S0261-5177(98)00036-3.

Thomas, H. and Thomas, R. (1998). The implication for tourism of shifts in British local governance. Progress in Tourism and Hospitality Research, 4(4), 295-306. doi: 10.1002/(SICI)1099-1603(199812)4:4<295:AID-PTH115>3.0.CO;2-0.

Zahn, F. (1978). A flow of funds analysis of crowding out. Southern Economic Journal, 136153. doi: $10.2307 / 1057622$.

Zugasti, C. A. A., García, R. G., \& Maldonado, J. S. (2001). The effects of public infrastructure on the cost structure of Spanish industries. Spanish Economic Review 3(2), 131-150. doi: 10.1007/PL00013587. 